\title{
ENHANCEMENT OF LEARNING THROUGH FIELD STUDY
}

\author{
G.W.T.C. Kandamby \\ Institute of Technology, University of Moratuwa (Sri Lanka) \\ kndamby@yaboo.com
}

Received February 2018

Accepted May 2018

\section{Abstract}

Learning is more concerned in engineering education as students need to do deep learning to understand the engineering principles for practice. Engineering is a practicing profession. Therefore, providing learning environment is required for the subjects of engineering disciplines to enable students to learn in depth. By knowing this phenomenon, field study was conducted as a group study for the civil engineering subject of building construction allowing students to learn and gain knowledge by observing construction activities in construction projects in addition to the lectures in usual classroom. At the end of the study, it is found that field study is useful for learning and students acquire knowledge and understand the application of theory at real situation. In addition, students develop skills for working as a team by organizing their works, sharing knowledge, discussing with relevant technical personnel at work site and achieving the targets within the given time frame. It is realized that teacher's role is vital to make the study successful in the ways of organizing field study, conducting discussion classes to assist students, monitoring the progress and giving the feedback of the students' performance during the course of field study producing excellent results while satisfying the objectives of both teacher and students.

Keywords - Learning, Engineering education, Field study, Team work.

\section{To cite this article:}

Kandamby, G.W.T.C. (2018). Enhancement of learning through field study. Journal of Technology and Science Education, 8(4), 408-419. https://doi.org/10.3926/jotse.403

\section{Introduction}

Engineering education requires the basic knowledge in mathematics and science which is usually obtained by following ordinary and advance level courses in school education. Students are able to select the suitable course by getting the required qualification from the school level education and acquire the engineering knowledge in desired engineering disciplines as appropriate engineering courses are available in higher education. Subjects in engineering education comprise of theories and practices which needs to be delivered in appropriate ways to enhance the knowledge, skill and attitude of the students to get the suitable employment in the field of engineering. Delivering methods are to be designed by the teachers suitably as the aim of learning engineering subjects is to apply the theory in real practice. Usual practice of delivering engineering subjects is through lectures, tutorials and laboratory experiments. Good learning environment is necessary for students to learn and understand the subjects well. Students learn in many ways, by seeing and hearing; reflecting and acting; reasoning logically and intuitively; memorizing and 
visualizing (Felder, 1988). The method of teaching is to be designed by understanding the learning styles of the students and the environment is to be arranged to encourage and motivate students for learning the engineering subjects. Field study was introduced as an assignment from 2014 for first year students in order to give good learning environment for students to gain more knowledge by observing building construction activities at construction project. Students had the opportunity to learn civil engineering principles relevant to the field of construction by observing the way it is used at real construction projects when they start their engineering education. Students enter engineering study without understanding the realities of either their degree program or engineering work, and without a sense of motivation and commitment (Bennett, Kapoor, Rajinder \& Maynard, 2015). In addition, they had a chance to understand the application of modern technology in construction field other than they have learned the application in the classroom. After completing this course, these students will be employed in the construction field where different category of people work together to achieve their common target of completing the project in time with the given cost limit. Students were able to understand how they work as a team, discuss with technical staff at site and obtain useful information relevant to their subject.

\subsection{Course Details}

Building construction and draughtmanship is a module of civil engineering technology under National Diploma in Technology program conducted in Sri Lanka (Kandamby, 2017) where students are selected by considering General Certificate of Education Advanced Level science and mathematics stream examination. This module is in first year of three-year program and students are capable enough to understand the civil engineering principles applicable for studying technology of building construction. Total period of coverage of the module is two hours lectures and three hours drawing practical per week for 30 weeks. Main objectives of this subject are to give the knowledge of properties of building materials, selection of them for applying for constructions and the way of constructing building components by following the correct techniques while developing students' skill for drawing the building components. At the end of the year, written examination is conducted for assessing the students' performance which is three-hour paper with descriptive questions and drawings.

\section{Research Objectives}

Objectives of this study are to determine whether;

1. The discussion classes held during the process of field study is successful.

2. Significant knowledge is gained from field study.

3. The team building of students is improved by engaging field study.

4. Teacher-student relationship is improved by the total process under 1, 2, and 3 above.

\section{Literature Review}

\subsection{Engineering Education}

Engineering is between science and society and is concerned with systematic principles of science and mathematics in order to conclude scientific results for improving real life (Grismon, 2002). The Merriam-Webster's Collegiate Dictionary defines engineering as the application of science and mathematics by which the properties on matter and the sources of energy in nature are made useful to people (Chanson \& James, 1998). The existing teaching and learning strategies or culture in engineering programs is outdated and need to become more student-centered (Mills \& Treagust, 2014). Teaching and learning has considerable attention over the past several years in higher education. Engineering is foremost a practical profession. It is a discipline where a combination of factors, including difficulty of the subject and mismatching of student and academic expectations exist (Wills, 2008). Engineering applications and normal engineering practice are often a combination of theory plus practical constraints. One of the skills of engineering educator is to be able to demonstrate the interface between engineering theory and practical limits (Chanson \& James, 1998). Majority of engineering and science programs, across the world, 
are 'delivered' (itself a word which implies teaching rather than learning) by means of lectures, tutorials and laboratory classes (Goodhew, 2010). Most engineering courses other than laboratories emphasize concepts rather than facts and use primarily lectures and reading (words, symbols) to transmit information (Felder, 1988). Lecture is the most existing teaching method in engineering degree programs. It is a talk or verbal presentation given by a lecturer, trainer or speaker to an audience (Sajjad, 2006). Knowledge can be acquired by mechanism other than intentional learning (Nesbit \& Mayer, 2010). Research and science were closely connected in the formation of technology and were the basis in engineering education (Graaff, 2016). Education is not fulfilled until the theoretical concepts learned in the classroom are applied (Paez \& Rubio, 2015). Engineering education remains similar to that practiced in the 1950's, chalk and talk with large classes and single-discipline, lecture-based delivery the norm, particularly in early years of study (Scott, 2014). Learning from practical cases is an essential factor in engineering education. Out of classroom learning experiences can engage students in the synthesis of science and technology and help develop their inquiry skills through active location-sensitive discourse with peer learners (Ryokai, Agogino \& Oehlberg, 2012). Effective learning experiences are those support the development of deep understanding concepts and general principles, the development of skills, both technical and professional, and the application of knowledge and skills to problems (Litzinger, Lattuca, Hadgraft, \& Newstetter, 2011). Teachers can support students to undergo effective learning process. It will help them to organize new information, link it to their existing knowledge and use memory aids to retrieve information (Eady \& Lockyer, 2013; Kandamby, 2017).

\subsection{Field Study for Learning}

Research related to field studies in 1970s, 1980s, and 1990s focused on the learning potential of informal learning environments like museum, zoos, planetaria or outdoor settings (DeWitt \& Storksdieck, 2008). Many instructional disciplines and areas such as art, photography, forestry, biology, geology, geography, physics, physical education, ecology, astronomy, botany, history, agriculture, zoology, political science, environmental horticulture, English offer some types of field or practical experience (Wilson, 2011). Educationalists use work-based learning to denote how learning takes place not only a school classroom through teaching, but also in the workplace through observing, discussing and acting in different social worlds (Corradi, Verzelloni \& Gherardi, 2010). Environmental educators are aware of the importance of brining real-world experiences to their teaching and students must integrate in-school environmental literacy with out-of-school natural world experiences (Wang \& Carlson, 2011). Outdoor environment provides students with opportunities to be involved in tasks that resembles how scientists work, a requirement that is needed in almost every science syllabus (Esteves, Fernandes \& Vasconcelos, 2015). Field-based approach is effective in helping students to achieve the knowledge required to fulfil the natural Science syllabus learning objectives, as well as to develop other competencies such as scientific reasoning and inquiry capacities (Esteves, Fernandes \& Vascobcelos, 2015). Krepel and Diwall (1981), defined field trip as a trip arranged by the school and undertaken for educational purpose in which the students go to places where materials for instruction may be observed and studied directly in their functional setting. Nowadays field study forms part of the curriculum of courses from a broad spectrum of sciences including geology, biology, archaeology, history as well as from various social sciences, while it is often implemented in formal tuition as part of the practical exercise undertaken by the students (Vassala, 2006). The field programme provides an opportunity to apply previous knowledge, review real examples set in a worldly framework, and opportunity to be involved, physically with real situations in the field (Wilson, 2011). It also found that the field trip experiences enhanced students' understanding of process of science, improved students' attitude towards biology and significantly influenced their biology achievement (Patrick, 2010). Engineering is also based on science which requires out door learning environment as other disciplines. Almost every task undertaken in professional practice by an engineer will be in relation to a project which is more directed to the application of knowledge (Scott, 2014; Mills \& Treagust, 2014). Students who participate in project-based learning are generally motivated, understanding the application of their knowledge in practice and they demonstrate better teamwork and communication skills (Mills \& Treagust, 2014). Knowledge can be acquired by mechanism other than intentional learning 
(Nesbit \& Mayer, 2010). The field trip should be placed early in the concrete part of the total learning activity and should be focused mainly on concrete interaction between the students and the environment (Orion \& Hofstein, 1994). The material presented should be a blend of concrete information (facts, data, and observable phenomena) and abstract concepts (principles, theories, mathematical models) (Felder, 1988). Field trips create opportunities for students to acquire practical technical skills alongside individual and social experiences (Demirkaya \& Atayeter, 2011). Field study is an additional learning activity which provide real learning environment for students to learn from observations at fields. Much of the learning makes use of observations, reflection on observations, experimentations with phenomena and the use of firsthand data and daily experiences (Bloom, 1984). Through the students' discussions with engineers and technicians during the visit, there is an obvious indication that the students have gained a lot of knowledge as a result of the field trip (Paez, \& Rubio, 2015). It demonstrates an increase in their motivation to learn as well as their desire to know more about the technology (Paez, \& Rubio, 2015). The field study is an educational technique, which makes the educational process more active, helps the students to work in real situations and to develop skills, competencies and positive attitudes through activation of their existing ones (Vassala, 2006). Field studies are essential to illustrate real professional situations and the complex interactions between all engineering and non-engineering constraints (Chanson \& James, 1998). On the field, the students, either in groups or independently, are assigned certain activities which can vary and their nature depends on their aims and objectives as well as the opportunities offered by each particular field. Activities on the field can include observation and comparison, mapping, sample taking, taking of photographs, etc. (Vassala, 2006). Based on final exam scores analyzed for the undergraduate students that attended the fieldtrip have performed better, when comparing to those that did not attend (Paez, \& Rubio, 2015). From the study, it was found that all the groups of students showed positive attitudes and gained some knowledge after the field trip, achieved significantly higher scores on the knowledge test and gained more positive attitudes than the others (Orion \& Hofstein, 1994). As they work as a group, they share what they are experiencing with others (Wilson, 2011). If students have positive feelings on a field trip, such as joy, interests love and satisfaction, the field trip is more likely to achieve its predetermined learning goals (Wang \& Carlson, 2011). Orion and Hoystein (1994) and Michie (1998) indicated that field trips providing first-hand experience, stimulating interest and motivation in science, giving meaning to learning and interrelationship and it supported for personal social development (Patrick, 2010). Cognitive and affective learning can occur as a result of class visits to out-of-school settings and learning outcomes are fundamentally influenced by the structure of the field trip, setting novelty, prior knowledge and interest of the students, the social context of the visit, teacher agendas, students experiences during field trip and the presence or absence and quality of preparation and follow up (DeWitt \& Storksdieck, 2008).

\subsection{Assessment and Feedback}

The general term assessment is to refer to all those activities undertaken by teacher and by their students in assessing themselves that provide information to be used as feedback to modify teaching and learning activities (William, 2011). Assessment was used primarily to describe processes of evaluating the effectiveness of sequences of instructional activities when the sequence was completed (William, 2011). Assessment for learning has disseminated four interventions: questioning, feedback through marking, peer- and self-assessment, and formative use of summative tests (Taras, 2010). Formative assessment is concerned with how judgments about the quality of student responses (performance, pieces or works) can be used to shape and improve the student's competence by short-circuiting the randomness and inefficiency of trial-and-error leaning (Sadler, 1989). It is part of teaching methodology and has more to do with teachers than learners (Taras, 2010). Summative assessment tests are designed to judge the extent of students' learning of the material for the purpose of grading, certification etc. (Taras, 2010). It contrasts with formative assessment in that it is concerned summing up or summarizing the achievement status of student and is geared towards reporting at the end of course of study especially for the purpose of certification (Sadler, 1989). Students need feedback on their understanding that allows them to grow as learners and sharpens their understanding of specific subject matter (Fink, Ambrose \& Wheeler, 2005). 
Students want to receive critical, constructive feedback; they find it meaningful and useful for future learning (William, 2011). Feedback is a key element in formative assessment and is usually defined in term of information about something that has been or is being done successfully (Sadler, 1989). Feedback should not be so detailed and specific that it scaffolds the learning so completely that the students do not need to think for themselves (William, 2011). Feedback is seen as a primarily component in formative assessment and one of the factor that have the strongest influence on learning (Havnes, Smith, Dysthe, \& Ludvigsen, 2012). The teacher - student relationship is one factor that may influence on how the students relate to feedback (Ruiz-Primo, 2011). Students use feedback to monitor the strengths and weaknesses of their performances and teachers use feedback to make programmatic decisions with respect to readiness, diagnosis and remediation (Sadler 1989). Understanding the principles of learning and how they impact teaching can help teachers to create new and more powerful form of learning (Fink, Ambrose \& Wheeler, 2005). Today, student ratings of instruction are widely used for the purpose of making personnel decisions and faculty development recommendations (Scriven, 1995). Students are certainly qualified to express their satisfaction or dissatisfaction with the experience. They have a right to express their opinions in any case, and no one else can report the extent to which the experience was useful, productive, informative, satisfying, or worthwhile. Students need feedback on their understanding that allows them to grow as learners and sharpens their understanding of specific subject matter (Fink, Ambrose \& Wheeler, 2005). Staff needs feedback too. Teachers need to know what was difficult and what was easy, and ideally why common errors or misconceptions occurred. Teacher should regularly ask feedback questions (e.g. at the end of a test, as suggested above) and review the errors students make (Goodhew, 2010). After nearly seven decades of research on the use of student evaluations of teaching effectiveness, it can safely be stated that the majority of researchers believe that student ratings are a valid, reliable, and worthwhile means of evaluating teaching (Wachtel, 1998). Teachers need to know what was difficult and what was easy, and ideally why common errors or misconceptions occurred. You should regularly ask feedback questions (e.g. at the end of a test, as suggested above) and review the errors students make (Goodhew, 2010).

\section{Methodology}

\subsection{Implementation of Field Study}

Aim of field study was to provide a good learning place for students to observe and understand the application of building construction technology which they have learned from the lectures. Since the subject was new to the students and there were possibilities of finding good building work sites all over the areas, field study could be arranged suitably. It was carried out as a group study with maximum of eight students in a group whose home towns were nearby. Students were asked to select a building construction site in its initial construction stage located close to their home town. Learning process was designed covering the total contents of the proposed area of the module by referring the construction project. Written assignment was prepared accordingly and given during the first term to enable students to start site visit in time. They were asked to have two site visits within their first two vacations and complete the work during the third term (Course has three terms during the academic year). Tasks given in the assignment were clearly directed to students to learn by observing construction activities and record the necessary information. Permission was taken from the project managers of these work sites to carry out the study without disturbing to their work. Site engineers and engineering assistants were asked to help students by clarifying their problems and allowing them to inspect the work as stated in the assignment. Before commencing the first site visit, tasks given in the assignment were clearly explained to students by conducting a discussion class separately for each group under a tutor. On this occasion students had a chance to clarify their problems and get awareness of this study. Students were asked to maintain individual field book for recording the observations along with suitable sketches. Teacher assisted students to carry out the study without any difficulties by clarifying their problems or issues they faced during the study. A leader was appointed by the group members of each group to carry out the work as a team and complete their tasks during the given period. Students shared knowledge by discussing the work at site and in the classroom by obtaining assistance from the tutors in the discussion classes. 


\subsection{Evaluation of Students}

Students were asked to submit their field books to the teacher after each site visit for getting feedback for his or her performance of learning. Feedback for the visits was indicated by giving clear statements and the marks out of 25 . Using the given feedback in their field books students were able to understand the improvement required for the next site visit and an additional visit was allowed if necessary to cover the total content of the study. At the end of whole study, students were asked to discuss the information collected individually and prepare a group presentation (for batch 2014/2015) or a group report (for batch 2015/2016). Students were then assessed by the panel from the presentations individually and final marks were arrived by considering both presentation and the marks received for their field books. This evaluation procedure was changed in 2016 replacing presentation by a group report where individual student was asked to present a chapter of the report. Students were then evaluated by considering marks obtained both from report and the marks received for the field book.

\section{Data Collection and Analysis}

A questionnaire was designed to collect the students' feedback for this learning exercise under four areas of study from the batches of 2014/2015 and 2015/2016 after the end examination. While collecting the comments, questions in the questionnaire were explained clearly in the classroom to enable students to understand and present the correct rating. Total numbers of students were 63 in 2014/2015 batch and 60 in 2015/2016. Students' ratings collected from the questionnaire were considered and entered them in the excel sheet for the analysis. Two excel sheets were prepared for two batches separately under four headings of this research objectives enabling the summation of the scores of each questions.

\subsection{Discussion Classes}

\begin{tabular}{|c|c|c|c|c|c|c|c|c|c|c|c|c|}
\hline \multirow[b]{3}{*}{ Studied Area } & \multicolumn{12}{|c|}{ Number of students and rating } \\
\hline & \multicolumn{6}{|c|}{2015 (63 students) } & \multicolumn{6}{|c|}{2016 (60 students) } \\
\hline & 1 & 2 & 3 & 4 & 5 & $\begin{array}{l}\text { Total of } \\
4 \text { and } 5\end{array}$ & 1 & 2 & 3 & 4 & 5 & $\begin{array}{l}\text { Total of } \\
4 \text { and } 5\end{array}$ \\
\hline Clarity of field study objectives & 0 & 1 & 7 & 36 & 19 & 55 & 0 & 0 & 2 & 36 & 22 & $58(97 \%)$ \\
\hline Guidance of collecting information & 0 & 0 & 1 & 34 & 28 & $62(98 \%)$ & 0 & 0 & 4 & 30 & 25 & 55 \\
\hline Guidance for entering records & 0 & 0 & 3 & 39 & 20 & 59 & 0 & 0 & 8 & 32 & 20 & 52 \\
\hline $\begin{array}{l}\text { Adequacy of time frame for } \\
\text { discussion }\end{array}$ & 0 & 0 & 8 & 41 & 12 & $53(84 \%)$ & 0 & 2 & 13 & 24 & 20 & $44(73 \%)$ \\
\hline $\begin{array}{l}\text { Assistance for preparing } \\
\text { presentation or the report }\end{array}$ & 0 & 0 & 3 & 30 & 30 & 60 & 0 & 3 & 12 & 28 & 16 & 44 \\
\hline
\end{tabular}

Table 1. Discussions held in classroom

Success of conducting discussion classes for the field study was analyzed under five questions stated in Table 1. Rating 4 and 5 represent as agree and strongly agree giving high positive response whereas rating 1,2 and 3 represent strongly disagree, disagree and neither agree nor disagree giving negative response.

Majority of the students have rated 4 and 5 . Addition of each 4 and 5 ratings are almost equal except for the areas on given time frame for the discussion and assistance for preparing presentations. It was understood that teacher has made less attention on these two areas in 2016. Majority of the students $84 \%$ to $98 \%$ in 2015 and $73 \%$ to $97 \%$ in 2016) have understood that discussion classes are useful for better learning by getting clear objectives of the study, guidance for collecting information and recording them in the field books, support for preparation of presentations or reports. Since evaluation of students was done in the process of field study by giving marks by observing the entries in field books, students have felt that they obtained good support from the teacher to learn the subject while carrying out the field study. 


\subsection{Knowledge Gained}

This area was analyzed under five areas as indicated in Table 2.

\begin{tabular}{|c|c|c|c|c|c|c|c|c|c|c|c|c|}
\hline \multirow[b]{3}{*}{ Studied Area } & \multicolumn{12}{|c|}{ Number of students and rating } \\
\hline & \multicolumn{6}{|c|}{2015 (63 students) } & \multicolumn{6}{|c|}{2016 (60 students) } \\
\hline & 1 & 2 & 3 & 4 & 5 & $\begin{array}{l}\text { Total of } \\
4 \text { and } 5\end{array}$ & 1 & 2 & 3 & 4 & 5 & $\begin{array}{l}\text { Total of } \\
4 \text { and } 5\end{array}$ \\
\hline $\begin{array}{l}\text { Time spent for the field study is } \\
\text { useful }\end{array}$ & 0 & 0 & 0 & 12 & 51 & $63(100 \%)$ & 0 & 0 & 4 & 22 & 34 & $56(93 \%)$ \\
\hline Interesting study & 0 & 0 & 1 & 14 & 48 & 62 & 0 & 1 & 5 & 23 & 31 & 54 \\
\hline Acquire knowledge on B.C. & 1 & 0 & 8 & 15 & 38 & $53(84 \%)$ & 0 & 0 & 5 & 30 & 25 & 55 \\
\hline Covered more details & 0 & 0 & 3 & 34 & 26 & 60 & 0 & 1 & 5 & 28 & 25 & $53(88 \%)$ \\
\hline Support for end written paper & 0 & 7 & 15 & 28 & 13 & $41(65 \%)$ & 1 & 1 & 13 & 33 & 12 & $45(75 \%)$ \\
\hline
\end{tabular}

Table 2. Knowledge gained for subject area

Ratings under the studied areas of knowledge gained were in similar range for both years towards to high rating of 4 and 5. Majority of students (84\% to $100 \%$ in 2015 and $88 \%$ to $93 \%$ in 2016) have expressed that time spent for the study was useful, study was interesting and acquired knowledge for the subject of building construction. Since there was no such specific questions related to the field study in the end examination paper, $65 \%$ to $75 \%$ of students have only rated the field study has supported for end written paper. But the students were able to answer the questions using the knowledge gained from the field study as all activities observed in the field visits were related to the building construction technology. When considering the total results presented in Table 2 for knowledge gained through the field study, it can be stated that students have learned the subject while spending time usefully with interest.

\subsection{Building Team Work}

Building team work among students is analyzed by considering four areas as shown in Table 3. Majority of the students ( $92 \%$ to $98 \%$ in 2015 and $83 \%$ to $90 \%$ in 2016) have participated the work as a team successfully by organizing site visits, achieving total contents of the study during the given period, preparing presentation or the report at the end of the work and maintaining good friendship among colleagues. When considering the total results on building team through field study, it can be stated that students have engaged the given task successfully and build good relationship among them.

\begin{tabular}{|c|c|c|c|c|c|c|c|c|c|c|c|c|}
\hline \multirow[b]{3}{*}{ Studied Area } & \multicolumn{12}{|c|}{ Number of students and rating } \\
\hline & \multicolumn{6}{|c|}{2015 (63 students) } & \multicolumn{6}{|c|}{2016 (60 students) } \\
\hline & 1 & 2 & 3 & 4 & 5 & $\begin{array}{l}\text { Total of } \\
4 \text { and } 5\end{array}$ & 1 & 2 & 3 & 4 & 5 & $\begin{array}{r}\text { Total of } \\
4 \text { and } 5\end{array}$ \\
\hline Organization of site visit & 0 & 2 & 1 & 15 & 45 & 60 & 0 & 1 & 5 & 29 & 25 & $54(90 \%)$ \\
\hline Achievement of given tasks & 0 & 0 & 5 & 20 & 38 & $58(92 \%)$ & 1 & 1 & 5 & 33 & 20 & 53 \\
\hline Preparation of presentation & 0 & 0 & 1 & 21 & 41 & $62(98 \%)$ & 0 & 3 & 5 & 25 & 25 & $50(83 \%)$ \\
\hline Good friendship among colleagues & 1 & 1 & 3 & 13 & 46 & $59(94 \%)$ & 1 & 0 & 6 & 17 & 36 & $53(90 \%)$ \\
\hline
\end{tabular}

Table 3. Building team work 


\subsection{Teacher Student Interaction}

Teacher and students' interaction was analyzed through six areas. Majority of students (84\% to $98 \%$ in 2015 and $83 \%$ to $92 \%$ in 2016) have stated that there were good interaction with teacher and students for organizing site visits, allowing students to ask questions during the discussion classes, appreciating students' good ideas on this study and assisting for the completion of the total assignment work. Students in both years (73\% in 2015 and $70 \%$ in 2016) have expressed that there was an improvement in relationship between teacher and the students due to this field study.

\begin{tabular}{|c|c|c|c|c|c|c|c|c|c|c|c|c|}
\hline \multirow[b]{3}{*}{ Studied Area } & \multicolumn{12}{|c|}{ Number of students and rating } \\
\hline & \multicolumn{6}{|c|}{2015 (63 students) } & \multicolumn{6}{|c|}{2016 (60 students) } \\
\hline & 1 & 2 & 3 & 4 & 5 & $\begin{array}{r}\text { Total of } \\
4 \text { and } 5\end{array}$ & 1 & 2 & 3 & 4 & 5 & $\begin{array}{r}\text { Total of } \\
4 \text { and } 5\end{array}$ \\
\hline Organizing site visit & 0 & 0 & 3 & 30 & 30 & 60 & 0 & 2 & 7 & 30 & 20 & $50(83 \%)$ \\
\hline $\begin{array}{l}\text { Encouraging students to ask } \\
\text { questions }\end{array}$ & 0 & 0 & 6 & 25 & 21 & 46 & 0 & 0 & 6 & 36 & 18 & 54 \\
\hline $\begin{array}{l}\text { Appreciation of students' good } \\
\text { ideas }\end{array}$ & 0 & 0 & 1 & 33 & 29 & $62(98 \%)$ & 0 & 0 & 5 & 32 & 23 & $55(92 \%)$ \\
\hline $\begin{array}{l}\text { Supporting for completion of } \\
\text { assignment }\end{array}$ & 0 & 0 & 8 & 31 & 23 & 54 & 0 & 0 & 7 & 30 & 22 & 52 \\
\hline $\begin{array}{l}\text { Supporting for preparation of } \\
\text { presentation or report }\end{array}$ & 1 & 1 & 8 & 31 & 22 & $53(84 \%)$ & 0 & 3 & 4 & 35 & 17 & 52 \\
\hline $\begin{array}{l}\text { Improving teacher-student } \\
\text { relationship }\end{array}$ & 0 & 1 & 15 & 22 & 24 & $46(73 \%)$ & 0 & 2 & 16 & 24 & 18 & $42(70 \%)$ \\
\hline
\end{tabular}

Table 4. Teacher-Students interaction
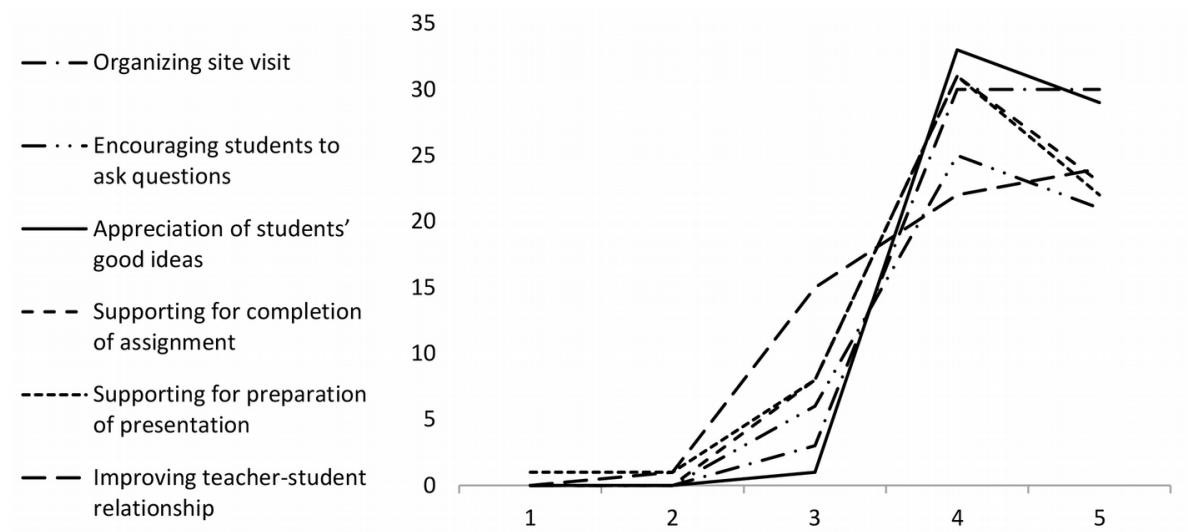

Figure 1. Teacher-Students interaction (2015)
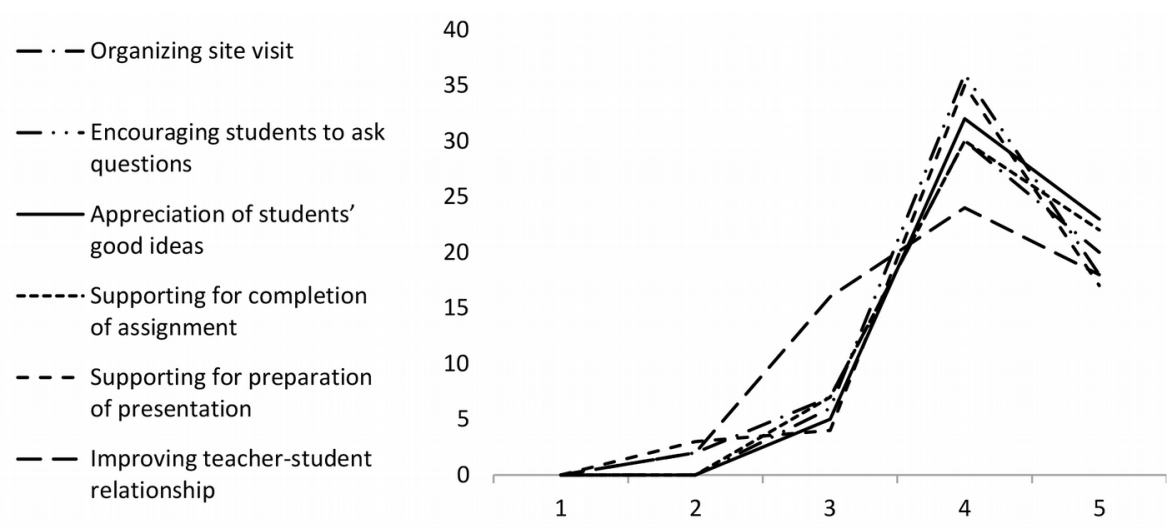

Figure 2. Teacher-Students interaction 
The graphs plotted for teacher-students interaction on horizontal scale: $1=$ strongly disagree, $5=$ strongly agree for six areas illustrate the similar shapes in both years. Peak values of all the areas studied are close to rating 4 . It indicates that teacher-students relationship has developed due to the activities in the total process of the field study.

\subsection{Roles of Teacher and Students}

It is found that $84 \%$ of students in 2015 and $72 \%$ of students in 2016 have agreed that they have learned building construction by participating field study in building construction site. This Learning process is analyzed under the listed areas of knowledge gained, team building, discussion classes and students' interaction which are now detailed under the roles of student and the teacher in order to find the necessity of improvements for future field studies in similar nature.

When considering the student's roles, more than $60 \%$ of students in year 2015 have strongly agreed that they performed well for all the areas listed in Table 5. But students in year 2016 were not able to achieve the same (strongly agree) results though they agree all these areas when undergoing this learning process.

\begin{tabular}{|l|l|c|c|c|c|c|c|c|c|}
\hline \multirow{2}{*}{} & \multicolumn{4}{|c|}{2015} & \multicolumn{4}{c|}{2016} \\
\cline { 2 - 11 } & Studied Areas & Agree & $\mathbf{\%}$ & $\begin{array}{c}\text { Strongly } \\
\text { Agree }\end{array}$ & $\mathbf{\%}$ & Agree & $\mathbf{\%}$ & $\begin{array}{c}\text { Strongly } \\
\text { Agree }\end{array}$ & \% \\
\hline \multirow{3}{*}{$\begin{array}{l}\text { Knowledge } \\
\text { gained and } \\
\text { team building }\end{array}$} & Acquiring knowledge & 15 & 24 & 38 & 60 & 30 & 50 & 25 & 42 \\
\cline { 2 - 11 } & Conducting Interest study & 14 & 22 & 48 & 76 & 23 & 38 & 31 & 52 \\
\cline { 2 - 11 } & Achieving given tasks & 20 & 32 & 38 & 60 & 33 & 55 & 20 & 33 \\
\cline { 2 - 11 } & $\begin{array}{l}\text { Maintaining relationships } \\
\text { among colleagues }\end{array}$ & 13 & 21 & 46 & 73 & 17 & 28 & 36 & 60 \\
\hline
\end{tabular}

Table 5. Student's roles

\begin{tabular}{|c|c|c|c|c|c|c|c|c|c|}
\hline \multirow{2}{*}{\multicolumn{2}{|c|}{ Studied Areas }} & \multicolumn{4}{|c|}{2015} & \multicolumn{4}{|c|}{2016} \\
\hline & & Agree & $\%$ & $\begin{array}{l}\text { Strongly } \\
\text { Agree }\end{array}$ & $\%$ & Agree & $\%$ & $\begin{array}{l}\text { Strongly } \\
\text { Agree }\end{array}$ & $\%$ \\
\hline \multirow{11}{*}{$\begin{array}{l}\text { Group } \\
\text { discussions } \\
\text { and students' } \\
\text { interaction }\end{array}$} & Organizing field study & 30 & 48 & 30 & 48 & 30 & 50 & 20 & 33 \\
\hline & Clarifying objectives & 36 & 57 & 19 & 30 & 36 & 60 & 22 & 37 \\
\hline & Encouraging students & 25 & 40 & 21 & 33 & 36 & 60 & 18 & 30 \\
\hline & Appreciating students' ideas & 33 & 52 & 29 & 46 & 32 & 53 & 23 & 38 \\
\hline & Guiding collection of information & 34 & 54 & 28 & 44 & 30 & 50 & 25 & 42 \\
\hline & Guiding entering records & 39 & 62 & 20 & 32 & 32 & 53 & 20 & 33 \\
\hline & Providing discussion time frame & 41 & 65 & 12 & 19 & 24 & 40 & 20 & 33 \\
\hline & $\begin{array}{l}\text { Supporting for completion of the } \\
\text { tasks }\end{array}$ & 31 & 49 & 23 & 37 & 30 & 50 & 22 & 37 \\
\hline & $\begin{array}{l}\text { Assistance for preparing } \\
\text { presentation / report }\end{array}$ & 30 & 48 & 30 & 48 & 28 & 47 & 16 & 27 \\
\hline & Support for end written paper & 28 & 44 & 13 & 21 & 33 & 55 & 12 & 20 \\
\hline & $\begin{array}{l}\text { Improving teacher-student } \\
\text { relationship }\end{array}$ & 22 & 35 & 24 & 38 & 24 & 40 & 18 & 30 \\
\hline
\end{tabular}

Table 6. Teacher's roles

When considering the teacher's roles, students have agreed the learning process under the areas listed in Table 6 (more than 73\% in 2015 and more than 70\% in 2016). Their responses for strongly agree are less than $48 \%$ for all areas listed. Therefore, it is found that teacher's roles have not been covered to achieve very high results of this field study. Field study is a good learning process for students to acquire knowledge for which teacher should attend the roles by organizing the study, clarifying the objectives, monitoring the students' performance, guiding for collecting information and making the 
presentation or the report after the field study and explaining the use of learning for attending end examination paper.

\section{Conclusions}

Literature review reveals that field studies have been practiced as an informal learning environment for most of the disciplines and now it is applied as a part of the curriculum of many courses. The research carried out for the field study under the discipline of civil engineering explains that field study is beneficial for the students to learn the subjects well by observing its application in the construction field. They acquire knowledge by learning construction activities and discussing with the technical staff at site. In addition, students are able to develop their skills to work as a team, collect information, record them, analyze and present as a form of a presentation or a report. For this total process, teacher's continuous support is necessary by observing their performance and directing them to achieve expected outcomes. In the case of continuous field visits, giving feedback by the teacher is required to achieve better outcome from the students. It is realized that teacher's role is very important to achieve high results from field study by overcoming the lagging areas identified as organizing the field study, monitoring the students' performance, guiding for collecting information, guiding for making the presentation or the report after the field study and maintaining good relationship with the students throughout the process of field study. The same process of field study can be applied for many instructional disciplines and areas identified from the literature review such as art, photography, forestry, biology, geology, geography, physics, physical education, ecology, astronomy, botany, history, agriculture, zoology, political science and environmental horticulture.

\section{Declaration of Conflicting Interests}

The author declared no potential conflicts of interest with respect to the research, authorship, and/or publication of this article.

\section{Funding}

The author received no financial support for the research, authorship, and/or publication of this article.

\section{References}

Bennett, D., Kapoor, R., Rajinder, R., \& Maynard, N. (2015). First year engineering students: Perceptions of engineers and engineering work amongst domestic and international students. The International Journal of the First Year in Higher Education, 6(1), 89-105. https://doi.org/10.5204/intjfyhe.v6i1.272

Bloom, B.S. (1984). The search for method of instruction as effective as one to one tutoring. Educational Leadership, 41(8), 4-17.

Chanson, H., \& James, P. (1998). Teaching case studies in reservoir siltation and catchment erosion. International journal of engineering education, 14(12), 265-275.

Corradi, G., Verzelloni, L., \& Gherardi, S. (2010). Through the practice lens; Where is the bandwagon of practice-based studies heading? Management Learning, 41(3), 265-283.

https://doi.org/10.1177/1350507609356938

Demirkaya, H., \& Atayeter, Y. (2011). A study on the experiences of university lecturers and students in the geography field trip. Procedia Social and Behavioral Sciences, 19, 453-461.

https://doi.org/10.1016/j.sbspro.2011.05.154

DeWitt, J., \& Storksdieck, M. (2008). A short review of school field trips: Key findings from the past and implications for the future. Visitor Studies, 11(2), 181-197. https://doi.org/10.1080/10645570802355562

Eady, M.J., \& Lockyer, L. (2013). Tools for learning: technology and teaching strategies. Learning to teach in the primary school, Queensland University of Technology, 71. http://ro.uow.edu.au/asdpapers/403 
Esteves, H., Fernandes, I., \& Vasconcelos, C. (2015). A field-based approach to teach geoscience: A study with secondday students. Procedia Social and Behavioral Science, 191, 63-67.

https://doi.org/10.1016/j.sbspro.2015.04.323

Felder, R.M. (1988). Learning and teaching styles in engineering education. Engr. Education, 78(7), 674-681.

Fink, D., Ambrose, S., \& Wheeler, D. (2005). Becoming a professional engineering educator: A new role for a new era. Journal of Engineering Education, 185-194. https://doi.org/10.1002/j.2168-9830.2005.tb00837.x

Goodhew, P.J. (2010). Teaching engineering. The Higher Education Academy, UK Centre for Materials Education, School of Engineering, University of Liverpool.

Graaff, E. (2016). Developments in engineering education and engineering education research in Europe. In Abdulwahed, M., Hasna, M., \& Froyd, J. (Eds.), Advances in Engineering Education in the Midle East and North Africa (11-33). Cham: Springer. https://doi.org/10.1007/978-3-319-15323-0_2

Grimson, J. (2002). Re-engineering the curriculum for the $21^{\text {st }}$ century. European Journal of Engineering Education, 27(1), 31-37. https://doi.org/10.1080/03043790110100803

Havnes, A., Smith, K., Dysthe, O., \& Ludvigsen, K. (2012). Formative assessment and feedback: Making learning visible. Studies in Educational Evaluation, 38, 21-27. https://doi.org/10.1016/j.stueduc.2012.04.001

Kandamby, G.W.T.C. (2017). Coursework for promoting teaching and learning. International Journal of Higher Education, 6(6), 129-138. https://doi.org/10.5430/ijhe.v6n6p129

Krepel, W.J., \& Duvall, C.R. (1981). Field trips: A guide for planning and conducting educational experiences. Washington: National Educational Association.

Litzinger, T.A., Lattuca, L.R., Hadgraft, R.G., \& Newstetter, W.C. (2011). Engineering Education and the Development of Expertise. Journal of Engineering Education, 100(1), 123-150. http://www.jee.org https://doi.org/10.1002/j.2168-9830.2011.tb00006.x

Michie, M. (1998). Factors influencing secondary school teachers to organize and conduct field trips. Australian Science Teachers Journal, 44(4), 43-50.

Mills, J.E., \& Treagust, D.F. (2014). Engineering education - Is problem-based or project-based learning the answer? Australasian Journal of Engineering Education. https://www.researchgate.net/publication/238670687

Nesbit, S., \& Mayer, A. (2010). Shifting Attitudes: The influence of field trip experiences on student beliefs, transformative Dialogues. Teaching \& Learning Journal, 4(2).

Orion, N., \& Hofstein, A. (1994). Factors that influence learning during a scientific field trip in a natural environment. Journal of Research in Science Teaching, 31(10), 1097-1119.

https://doi.org/10.1002/tea.3660311005

Paez, D., \& Rubio, L.A. (2015). The Use of Field Trips in the Context of Engineering Collaborative Teaching: Experiences of Hands-On Geomatics Activities in Colombia. Wisdom of the Ages to the Challenges of the Modern World Sofia, Bulgaria, 17-21.

Patrick, A.O. (2010), Effects of field studies on learning outcomes in Biology. Hum Ecol, 31(3), 171-177. https://doi.org/10.1080/09709274.2010.11906312

Ruiz-Primo, M.A. (2011). Informal formative assessment: The role of instructional dialogues in assessing students' learning. Studies in Educational Evaluation, 37, 15-24. https://doi.org/10.1016/j.stueduc.2011.04.003

Ryokai, K., Agogino, A., \& Oehlberg, L. (2012). Mobile learning with the engineering pathway Digital library. International Journal of Engineering Education. 28(5), 1119-1126. 
Sadler, D.R. (1989). Formative assessment and the design of instructional system. Instructional Science, 18, 119-144. https://doi.org/10.1007/BF00117714

Sajjad, S. (2006). Effective Teaching methods at higher education level. University of Karachi. Pakistan. http://class.web.nthu.edu.tw/ezfiles/669/1669/img/1381/1

Scott, N. (2014). Engineering education - Is problem-based or project-based learning the answer? Australasian Journal of Engineering Education. https://www.researchgate.net/publication/238670687

Scriven, M., (1995). Student rating offer useful input to teacher evaluation. Practical Assessment, Research and Evaluation, 4(7), 1-5.

Taras, M. (2010). Assessment for learning: assessing the theory and evidence. Procedia Social and Bebavioral Science, 2, 3015-3022. https://doi.org/10.1016/j.sbspro.2010.03.457

Vassala, P. (2006). The field study as an educational technique in open and distance learning. Journal of Distance Education, 7(4), 10-17.

Wachtel, H.K. (1998). Student Evaluation of College Teaching Effectiveness: A brief review. Assessment \& Evaluation in Higher Education, 23(2), 191-211. https://doi.org/10.1080/0260293980230207

Wang, H., \& Carson, S.P. (2011). Factors that influence student's satisfaction in an environmental field day experience. International Electronic Journal of Environmental Education, 1(2).

William, D. (2011). What is assessment for learning? Studies in Educational Evaluation 37, 3-14. https://doi.org/10.1016/j.stueduc.2011.03.001

Wills, L. (2008). Enhancing the first year experience for engineering students. The Higher Education Academy, Engineering Subject Centre. Loughborough, 1-28.

Wilson, J. (2011). Importance of field study programmes, Journal of Sierra Collage Natural History Museum, 4(1).

Published by OmniaScience (www.omniascience.com)

Journal of Technology and Science Education, 2018 (www.jotse.org)

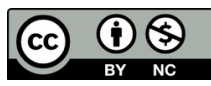

Article's contents are provided on an Attribution-Non Commercial 4.0 Creative commons International License.

Readers are allowed to copy, distribute and communicate article's contents, provided the author's and JOTSE journal's names are included. It must not be used for commercial purposes. To see the complete licence contents, please visit https://creativecommons.org/licenses/by-nc/4.0/. 